\title{
KAJIAN HIDROGEOMORFOLOGI MATAAIR DI SEBAGIAN LERENG BARAT GUNUNGAPI LAWU
}

\author{
Study of Spring Hidrogeomorphology on Part of West Slop \\ in Lawu Vulcano
}

Oleh:

Drs. Langgeng Wabyu Santosa, M.Si.

Jurusan Geografi Fisik, Fakultas Geografi, UGM

\begin{abstract}

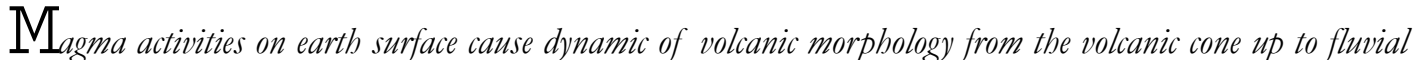
volcanic plain. The changing of morphology is always followed by different slope, composition and thickness of material, and break of slope. This geomorphological conditions result in groundwater emerges forming spring belt. Accordingly, wether such phenomena are also the case in the west slope of Lawn volcano is investigated in this reseach. Hydrogeomorphology approach is applied to study of the spring characteristic and distribution in the research area. The result research shows that the distribution pattern of springs in the west slope of Lawn volcano is not like spring belt perfectly, like the strato volcano generally. It is caused by erosion processes, mass wasting intensively, Lawu fault and other faults. Most springs flow on the volcanic slope and volcanic foot morphology.
\end{abstract}

Keywords: Spring, Break of Slope, Spring Belt, Morphology

\section{PENDAHULUAN}

\section{Latar Belakang Penelitian}

Mataair (spring) adalah pemusatan keluarnya airtanah yang muncul di permukaan tanah sebagai arus dari aliran airtanah (Tolman, 1937). Menurut Bryan (1919) dalam Todd (1980), berdasarkan sebab terjadinya mataair diklasifikasikan menjadi 2 , yaitu: mataair yang dihasilkan oleh tenaga non gravitasi (non gravitational spring) dan mataair yang dihasilkan oleh tenaga gravitasi (gravitational spring). Mataair yang dihasilkan oleh tenaga non gravitasi meliputi: mataair vulkanik, mataair celah, mataair hangat, dan mataair panas. Mataair gravitasi diklasifikasikan menjadi beberapa tipe, yaitu: mataair depresi (depresion spring) yang terbentuk bila permukaan airtanah terpotong oleh topografi; mataair kontak (contact spring) terjadi bila lapisan yang lulus air terletak di atas lapisan kedap air; mataair artesis (artesian spring) yang keluar dari akuifer tertekan; dan mataair turbuler (turbulence spring) yang terdapat pada saluran-saluran alami pada formasi kulit bumi, seperti goa lava atau joint.

Salah satu wilayah yang mempunyai potensi mataair besar adalah wilayah lereng gunungapi, dan di antara wilayah gunungapi yang mempunyai persebaran mataair yang cukup melimpah adalah lereng Gunungapi Lawu bagian Barat. Gunungapi Lawu merupakan gunungapi strato tua yang mempunyai potensi mataair cukup tinggi sebagaimana gunungapi strato muda, seperti Gunungapi Merapi. Pada gunungapi strato muda, umumnya mempunyai pola persebaran mataair yang melingkari badan gunungapi membentuk pola seperti sabuk, 
yang biasa disebut sabuk mataair (spring belt). Hal ini merupakan gejala pemunculan mataair yang khas dan umum terdapat pada gunungapi strato di Indonesia, khususnya di Pulau Jawa. Pada ketinggian-ketinggian tertentu terdapat jalur mataair (spring belt) yang berkaitan dengan sifat orohidrologinya, juga berkaitan dengan perubahan lereng yang diakibatkan oleh perubahan struktur batuan pembentuknya (Purbohadiwidjojo, 1967).

Gunungapi Lawu secara geomorfologis berada pada zona tengah Jawa Tengah. Zona ini merupakan suatu depresi yang diisi oleh endapan vulkanik muda dan termasuk dalam deretan Gunungapi Kuarter dengan bentuk strato. Aktivitas gunungapi pada zona ini umumnya menghasilkan batuan berkomposisi andesit sampai basalt, baik berupa batuan lepas dalam bentuk rempah-rempah gunungapi berbutir halus sampai kasar (piroklastik), maupun batuan padu dalam bentuk aliran maupun kubah lava (Pannekoek, 1949).

Pengendapan material hasil proses tersebut, pada akhirnya membentuk akuifer yang mempunyai porositas dan permeabilitas tinggi, khususnya pada morfologi lereng gunungapi hingga dataran fluviovulkanik. Hal ini lebih didukung lagi oleh adanya curah hujan yang jatuh di atas bentanglahan ini cukup tinggi. Persebaran mataair dengan berbagai debit aliran terdapat pada tubuh gunungapi bagian tengah (lereng gunungapi) hingga bawah (kaki gunungapi), dengan tempat pemunculan kurang lebih bersesuaian dengan tempat terjadinya perubahan kemiringan lereng (break of slope), yang mengindikasikan perubahan tingkat kelulusan batuan (Purbohadiwidjoyo, 1967). Suatu pertanyaan muncul: "Apakah konsepsi ini berlaku untuk. Gunungapi Lawu yang bertipe strato tua?"

\section{Tujuan Penelitian}

Tujuan penelitian ini adalah untuk mengetahui karakteristik dan pola agihan mataair pada setiap morfologi di sebagian lereng Barat Gunungapi Lawu.

\section{KERANGKA PEMIKIRAN TEO- RETIS}

\section{Tinjauan Pustaka}

Sutanto, dkk. (1980) dalam penelitiannya tentang persebaran mataair di lereng Gunungapi Merapi bagian selatan, merupakan suatu contoh yang menjelaskan tentang pola persebaran mataair pada tipe gunungapi strato, seperti halnya dengan Gunungapi Lawu. Hasil penelitian ini menunjukkan bahwa di wilayah lereng Gunungapi Merapi bagian selatan terbagi menjadi 3 (tiga) satuan pemunculan mataair, yaitu satuan mataair pada volcanic slope, satuan mataair volcanic foot, dan satuan mataair volcanic foot plain.

Pada satuan volcanic slope, keluarnya mataair disebabkan oleh kemiringan lereng yang cukup besar, sehingga air hujan hanya dapat merembes (infiltrasi) masuk ke dalam formasi piroklastis di atas formasi lava flow yang kedap air. Mataair yang muncul di daerah ini selain tergantung luas hutan sebagai penahan air hujan, juga tergantung lapisan tanah yang umumnya sangat tipis yang terbentuk karena pelapukan piroklastis atau aliran-aliran lava yang telah mengalami pelapukan. Debit mataair pada satuan ini relatif kecil, kecuali adanya rekahan (fracture) pada lava flow yang bergabung menjadi aliran yang cukup besar dan muncul di ujung volcanic slope atau bahkan di satuan volcanic foot. Pada satuan 
kaki volkan dijumpai jalur mataair (spring belt) yang terdapat pada ujung aliran lava Gunungapi Merapi Muda di bagian Barat, dan ujung aliran lava Gunungapi Merapi Tua di bagian timur. Pada satuan volcanic plain juga banyak dijumpai mataair sebagai akibat perbedaan kemiringan karena perubahan morfologi akibat perubahan tekstur batuan yang kasar ke tekstur halus.

Ardina (1985) menjelaskan tentang hubungan antara litologi (gunungapi tua, gunungapi muda, batugamping tua, dan batugamping muda) dengan debit matair yang keluar dari masing-masing formasi batuan tersebut. Hasil analisis statistik menunjukkan bahwa pada formasi gunungapi tua memberikan nilai korelasi sebesar 0,90 terhadap debit mataair, sedangkan pada gunungapi muda memberikan korelasi sebesar 0,95 terhadap debit mataair. Hal ini menunjukkan bahwa semakin tua umur batuan gunungapi, maka semakin kecil pengaruhnya terhadap debit mataair yang muncul. Hal ini dapat terjadi karena dalam perkembangannya semakin tua umur batuan gunungapi, maka proses pemadatan dan perekatan berjalan lebih intensif yang menyebabkan rongga antar butir menjadi kecil, sehingga nilai kesarangan dan kelulusannya juga kecil. Oleh karena itu debit mataairnya juga akan lebih kecil dibandingkan dengan debit mataair pada formasi gunungapi muda. Pada formasi batugamping umur Miosen memiliki debit mataair yang lebih besar dari pada batugamping yang berumur Pliosen. Hal ini dikarenakan perkembangan batugamping Miosen mengalami proses pelarutan yang lebih intensif, sehingga berakibat pada nilai kelulusan yang lebih besar dengan bertambahnya umur batugamping, akibatnya debit mataair yang muncul melalui zona pelarutan tersebut juga akan bertambah besar pula.
Curah hujan merupakan hal pokok yang berkaitan dengan keterdapatan mataair di suatu daerah, tetapi dengan litologi yang berbeda suatu daerah akan memiliki debit mataair yang berbeda dengan daerah lainnya. Bahkan di suatu daerah yang mempunyai curah hujan yang lebih tinggi dapat memiliki rata-rata debit mataair yang lebih rendah (sedikit) apabila litologinya tidak mendukung. Daerah dengan curah hujan dan litologi sama, seperti pada gunungapi muda, dapat memiliki debit mataair yang berbeda, karena susunan kimia batuannya yang berbeda (Ardina, 1985).

Murdiono (1972) melakukan penelitian tentang hidrogeologi pada tahun 19711972 di Surakarta-Sragen, Jawa Tengah. Menurutnya, hubungan antara jenis batuan dengan kondisi airtanah dan luah mataair pada masing-masing wilayah airtanah menunjukkan bahwa pada satuan pegunungan lipatan dijumpai mataair dengan debit yang kecil berkisar antara 0,4 hingga $5 \mathrm{lt} / \mathrm{dt}$; sedang pada satuan gunungapi muda mataair mempunyai kisaran debit yang cukup bervariasi, yaitu $<10 \mathrm{lt} / \mathrm{dt}$ hingga $>50 \mathrm{lt} / \mathrm{dt}$. Penelitian serupa juga dilakukan oleh Wara (1993) yang bertujuan untuk mengetahui hubungan antara debit dan kualitas mataair dengan kondisi topografi, litologi, hidrogeologi serta curah hujan. Hasil penelitian menunjukkan bahwa terdapat keterkaitan antara agihan dan debit mataair dengan kondisi litologi dan struktur batuan yang ada, seperti sesar dan kekar.

Abdulrahman (1990) melakukan penelitian mataair pada suatu daerah vulkanik yang tersusun atas beberapa formasi batuan berumur Kuarter dan Tersier. Umur batuan ini berpengaruh 
terhadap air yang dikandungnya, bahwa semakin tua umur batuan maka debit mataair umumnya makin kecil. Daerah yang tersusun oleh batuan vulkanis memiliki jauh lebih banyak mataair daripada yang berbatuan lain. Pada batuan yang berumur Kuarter terdiri atas material lepas dari hasil erupsi gunungapi berupa pasir dan kerikil, yang memungkinkan dijumpainya airtanah tertekan.

\section{Kerangka Teori}

Pergerakan airtanah pada berbagai tempat akan mengakibatkan airtanah keluar ke permukaan bumi sebagai mataair (spring) ataupun rembesan (seepage) dengan debit yang bervariasi. Faktor-faktor yang mempengaruhi karakteristik dan persebaran mataair antara lain: perubahan morfologi lereng, proses geomorfologis, jenis batuan, dan struktur geologis penyusunnya.

Perubahan morfologi yang ditandai oleh adanya tekuk lereng atau pemotongan topografi, akan menyebabkan pemunculan aliran airtanah dari dalam akuifer ke permukaan bumi, baik secara terpusat maupun rembesan. Perlapisan antara batuan yang bersifat porous, seperti bahanbahan piroklastis atau bahan-bahan aluvium di bagian atas, dengan batuan yang bersifat kedap air, seperti batuan beku di bagian bawah yang relatif kompak, juga akan menyebabkan mengalirnya airtanah melalui batas perlapisan tersebut, dan muncul sebagai mataair kontak. Demikian juga kedudukan antara satu perlapisan batuan dengan perlapisan yang lain, dan struktur geologis yang menyusunnya, seperti patahan, retakan, maupun perlipatan, merupakan faktor lain pengontrol pemunculan dan pola sebaran mataair. Pemunculan mataair di suatu tempat, juga tidak terlepas dari kedudukan lokasi itu sendiri, kaitannya dengan tenaga gravitatif yang mempengaruhinya maupun energienergi lain, seperti tekanan hidrostatis yang kuat akibat struktur perlapisan batuan yang sangat tebal (geyser), atau akibat dorongan energi magma pada daerah vulkanik. Proses-proses geomorfologis yang bekerja pada suatu daerah, sangat menentukan dinamika bentanglahan di wilayah tersebut. Hal ini secara langsung maupun tidak langsung, dalam jangka waktu yang lama akan mempengaruhi keberadaan dan karakteristik mataair di daerah tersebut. Oleh karenanya, untuk mempelajari karakteristik dan pola agihan mataair, dapat digunakan pendekatan hidrogeomorfologi. Artinya bahwa dengan mempelajari kondisi geomorfologi di suatu daerah, maka dapat diperkirakan dan dianalisis secara baik tentang karakteristik, persebaran, dan dinamika pemunculan mataair. Konsepsi ini juga sesuai diterapkan pada bentanglahan vulkanik, yaitu dengan mendasarkan pada variasi geomorfologi lereng, khususnya pada vulkanik tipe strato seperti Gunungapi Lawu.

Munculnya mataair di daerah vulkanik lebih disebabkan oleh tenaga dari dalam bumi, sebagai mataair non gravitasi. Daerah lereng Barat Gunungapi Lawu adalah daerah berbatuan gunungapi yang memiliki banyak mataair. Pada daerah yang berumur Kuarter terdiri atas material lepas hasil erupsi gunungapi berupa pasir dan kerikil, dan kemungkinan mempunyai airtanah tertekan, sehingga terdapat akumulasi air yang muncul secara melimpah ke permukaan berupa mataair. Daerah lereng Barat Gunungapi Lawu terdiri atas beberapa jenis batuan yang terdapat dalam formasi tertentu, sehingga dimungkinkan adanya variasi debit pada beberapa mataair. Pada batuan berumur kuarter terdapat kontak 
antara materi batuan bertekstur kasar dengan materi batuan yang bertekstur halus dan juga terdapat beberapa matair artesis pada jalur-jalur munculnya mataair (spring belt). Proses-proses geomorfologi vulkanik, baik yang bersifat endogen akibat gerakan magma ke permukaan bumi, maupun eksogen akibat aliran lava dan lahar, sangat menentukan perkembangan morfologi lereng dan bentanglahan Gunungapi Lawu secara keseluruhan. Sifat magma dan alirannya, menyebabkan pembentukan tipe strato pada gunungapi ini, dan perkembangan morfologi lereng, mulai dari kerucut, lereng, kaki, dataran kaki, hingga data- ran fluvial gunungapi. Kontak antara lapisan material Gunungapi Lawu Tua di bagian bawah yang relatif kedap air dengan bahan-bahan piroklastis Gunungapi Lawu Muda di bagian atas dan perubahan morfologi lereng yang ditandai oleh keberadaan tekuk-tekuk lereng, merupakan dua faktor penentu pemunculan mataair dan pola sebarannya. Di samping itu, keberadaan struktur-struktur patahan sedemikian rupa di lereng Barat Gunungapi Lawu, lebih menjadi faktor pengontrol kedudukan, karakteristik, dan pola persebaran mataair di daerah ini. Secara sistematis, kerangka pemikiran ini dituangkan dalam Diagram 1.

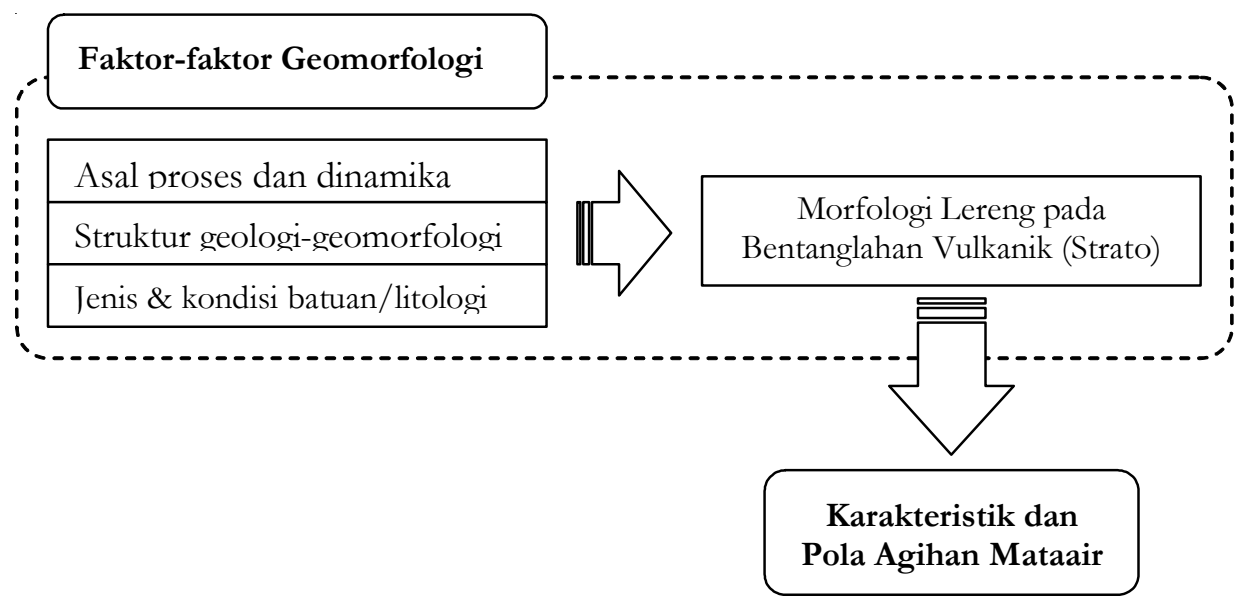

Diagram 1. Konsep dan Pemikiran Hidrogeomorfologi Mataair pada Bentanglahan Vulkanik

\section{CARA PENELITIAN}

Data dalam penelitian ini meliputi: morfologi lereng bagian Barat Gunungapi Lawu, tipe, persebaran, dan debit mataair yang ada di daerah penelitian. Tahapan penelitian mulai dari penyusunan peta dasar, survei lapangan, analisis data dan penyajiannya, disajikan pada Diagram 2.
Pengumpulan data dikelompokkan menjadi 2 (dua), yaitu: (i) data morfologi lereng yang diinterpretasi dari peta topografi dan geologi, dan (ii) data karakteristik mataair yang didapatkan berdasarkan hasil pengukuran langsung di lapangan secara systematic sampling dan didukung pula dengan data hasil-hasil penelitian terdahulu. Pengukuran debit mataair dapat dilakukan 


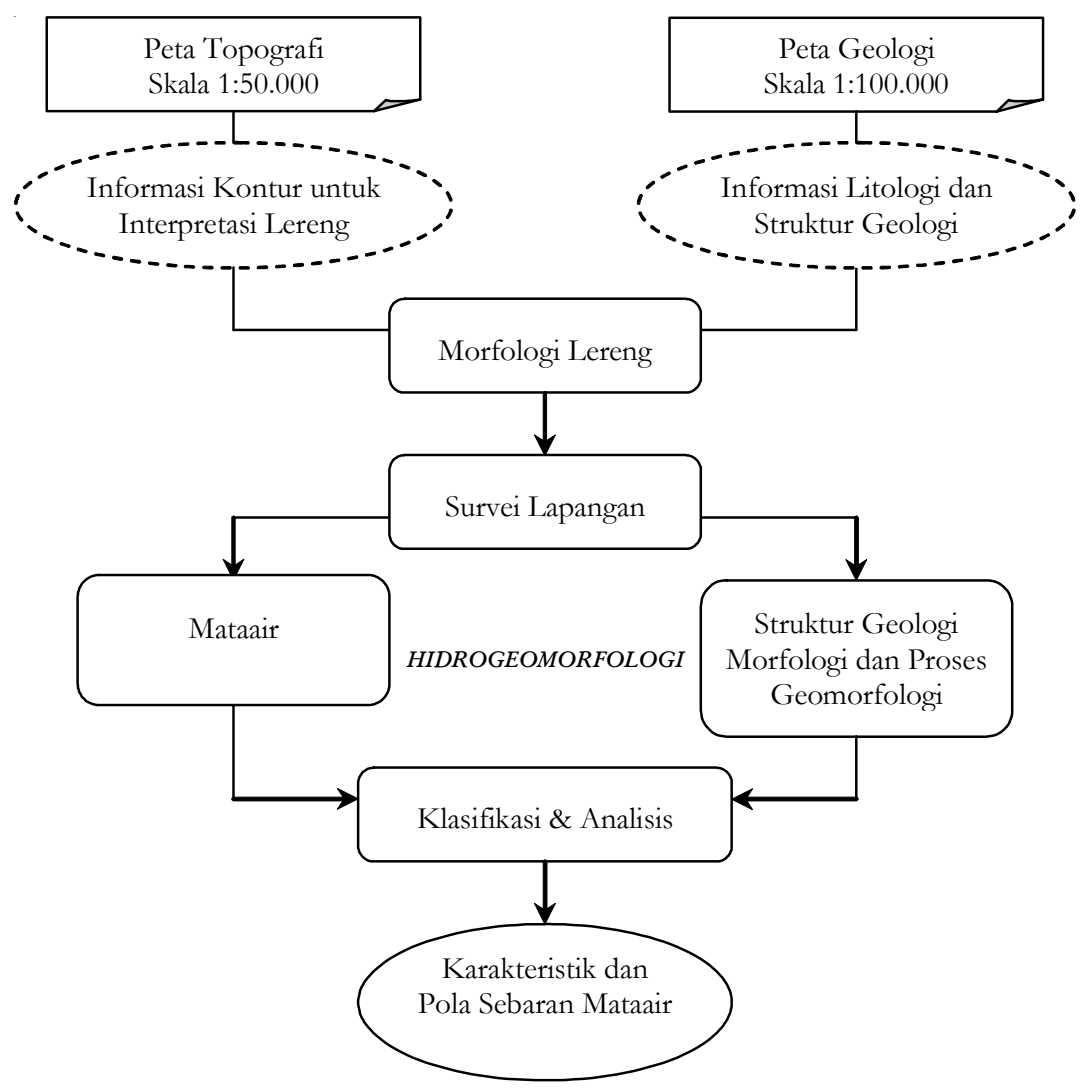

Diagram 2. Tahapan Penelitian

dengan merunut pada metode volumetrik, pelampung dan/atau injeksi, bergantung pada kondisi aliran dan morfometri saluran.

Cara analisis dilakukan secara spasial dan deskriptif. Analisis spasial berupa peta yang menjelaskan pola sebaran mataair pada berbagai morfologi lereng; sedangkan analisis deskriptif dilakukan untuk menjelaskan pola agihan mataair kaitannya dengan faktor-faktor yang mempengaruhi debit dan persebaran mataair di daerah penelitian. Klasifikasi mataair didasarkan atas sifat aliran, debit aliran, dan temperatur (Tolman, 1937; Meinzer, 1923 dalam Todd, 1980). Hubungan antara karakteristik dan persebaran pemunculan mataair dengan kondisi geomorfologi (morfologi lereng), dilakukan dengan cara tumpang-susun (over- lay) peta-peta topografi (lereng), geologi, dan plotting lokasi mataair hasil pengukuran lapangan.

\section{HASIL DAN PEMBAHASAN}

Geomorfologi Lereng Barat Gunungapi Lawu

Daerah penelitian secara administratif termasuk dalam wilayah Kecamatan Matesih, Tawangmangu, Ngargoyoso, dan Kecamatan Karangpandan, Kabupaten Karanganyar, Propinsi Jawa Tengah, dengan posisi koordinat $111^{\circ} 03^{\prime}-111^{\circ} 11^{\prime}$ BT dan $7^{\circ} 34^{\prime}-7^{\circ} 39^{\prime}$ LS.

Batuan Gunungapi Lawu dapat dipisahkan menjadi batuan Gunungapi Lawu Tua (kompleks Jobolarangan) dan 
batuan Gunungapi Lawu Muda. Gunungapi Lawu termasuk dalam jalur Gunungapi Kuarter. Aliran lava yang bersumber dari beberapa kerucut parasiter tersebar di bagian badan Gunungapi Lawu Tua dan Gunungapi Lawu Muda.

(a) Kompleks Gunungapi Lawu Tua (Gunung Jobolarangan)

- Breksi Jobolarangan (Qvjb) tersusun atas breksi gunungapi, setempat bersisipan lava andesit. Umumnya menempati bagian puncak kompleks Gunungapi Lawu Tua, yaitu di Kabupaten Karanganyar bagian selatan dan sedikit di bagian Timurlaut. Warna batuan kelabu kecoklatan, dan bila lapuk menjadi kemerahan. Menempati pada kemiringan lereng antara 30-50\%, dengan tebal lapisan mencapai puluhan meter. Di daerah penelitian kelompok ini disisipi lava andesit berwarna kelabu kehitaman. Contoh sisa breksi gunungapi yang dikelilingi endapan lahar adalah: Gunung Nguworak, Gunung Bulu, dan Gunung Kukusan di Baratlaut Gunungapi Lawu Tua.

- Lava Sidoramping (Qvsl) berupa lava andesit. Lava ini bertekstur alir yang berasal dari kompleks Sidoramping, Gunung Puncakdalang, Gunung Kukusan dan Gunung Ngampiyungan, yang secara umum mengalir ke arah Barat. Warna dominan kelabu tua dan tersusun atas plagioklas, kuarsa dan felspar.

(b) Kompleks Gunungapi Lawu Muda

- Batuan Gunungapi Lawu (Qvl), terdiri atas tuf breksian dan breksi tufaan bersisipan lava andesit. Tuf breksian berwarna coklat keme- rahan, umumnya lapuk dan berukuran 2-10 cm. Tersusun atas mineral andesit, kuarsa, felspar, kepingan kaca gunungapi, batuapung, dan sedikit piroksin serta ampibol. Felspar sebagian berubah menjadi lempung dan klorit, dengan tebal lapisan $>2$ meter. Breksi tufaan berwarna kelabu coklat, bila lapuk berwarna coklat kemerahan, memiliki ukuran antara 1-10 cm, dengan tebal lapisan $>5$ meter. Lava andesit berwarna kelabu, tersusun atas mineral plagioklas, felspar sedikit kuarsa dan mineral mafik. Umumnya berstruktur leleran dengan ketebalan lapisan sekitar 2 meter. Satuan batuan ini mempunyai persebaran luas, mulai dari kerucut, lereng, hingga kaki gunungapi.

- Lava Condrodimuko (Qvcl) terdiri atas lava andesit berwarna kelabu tua, yang tersusun atas mineral andesit, kuarsa, felspar, sedikit hornblende, piroksin, dan mineral bijih. Leleran yang berasal dari kawah Condrodimuko ini mengalir ke arah Baratdaya. Bagian Baratlaut dibatasi oleh sesar turun yang memotong puncak Gunungapi Lawu, sementara aliran yang ke Selatan dibatasi oleh sesar Cemorosewu. Satuan batuan ini mengalir dari kawah Gunung Banyuurip dan menempati morfologi kerucut hingga lereng gunungapi.

- Lava Anak Lawu (Qvcl) mempunyai karaktersitik seperti Lava Condrodimuko, yang keluar dari salah satu kerucut parasiter Lawu Muda di bagian Timurlaut, pada morfologi lereng gunungapi.

- Lahar Lawu (Qlla) berupa endapan lahar, yang terdiri atas andesit, ba- 
salt, dan sedikit batuapung bercampur dengan pasir gunungapi, membentuk perbukitan rendah ataupun mengisi dataran kaki gunungapi. Agihan cukup luas mulai dari Kecamatan Karangpandan hingga batas bagian Barat Kabupaten Karanganyar, yang menempati morfologi kaki hingga dataran kaki gunungapi.

(c) Batuan Terobosan Andesitis (Tma), dengan ukuran kristal antara 0,5-1 mm, tersusun atas mineral andesit, ortoklas, kuarsa, bijih, mikrolit plagioklas, dan silika. Sebagian besar felspar berubah menjadi klorit dan lempung. Batuan terobosan ini (Gunung Bangun) terdapat pada tekuk lereng antara morfologi kaki dan dataran kaki di bagian Baratdaya.

Pada lereng Barat Gunungapi Lawu terdapat struktur patahan yang cukup kompleks, yang dikontrol oleh dua sesar utama, yaitu Sesar Lawu dan Sesar Sidoramping. Sesar Lawu membentang arah Baratdaya-Timurlaut, yang bersesuaian dengan tekuk lereng antara morfologi lereng dengan kaki gunungapi, serta antara morfologi kaki dengan dataran kaki gunungapi. Di sekitar Sesar Lawu ini terdapat sesar-sesar diperkirakan yang relatif tegak-lurus, yaitu di sekitar jajaran kerucut parasiter Gunung Cemorobulus, Gunung Tempurung, dan intrusi andesitis Gunung Bangun. Sesar-sesar kecil diperkirakan ini, terbentang memotong kontur antara morfologi kaki hingga dataran kaki gunungapi. Sesar Sidoramping merupakan sesar utama yang memotong kawah parasiter Gunung Banyuurip dan kawah utama Gunungapi Lawu Muda dengan arah Utara-Selatan. Dua sesar lainnya terbentuk mulai dari kawah utama ke arah Timurlaut, dan ke arah Baratlaut memotong Sesar Lawu.

Menurut Pannekoek (1949), daerah penelitian termasuk dalam satuan geomorfologi deretan Gunungapi Kuarter berupa gunungapi strato, yang menghasilkan batuan berkomposisi andesitis sampai basaltis, baik berupa batuan lepas dalam bentuk rempah gunungapi berbutir halus sampai kasar, maupun batuan padu dalam bentuk aliran dan kubah lava. Keterdapatan airtanah ditentukan oleh kondisi morfologi dan sifat batuan terhadap air, baik disebabkan oleh kelulusan air karena terdapatnya ruang antar butir maupun terdapatnya celahan, rekahan, maupun struktur sesar.

Daerah penelitian merupakan bagian lereng Barat Gunungapi Lawu yang mempunyai topografi bertebing-tebing curam dan memiliki potensi pemunculan mataair yang cukup baik. Secara geomorfologi, daerah penelitian dapat dibagi ke dalam 4 satuan morfologi, seperti diuraikan berikut ini.

(a) Satuan Morfologi Kerucut Gunungapi (Volcanic Cone)

Satuan ini terletak di sekitar puncak Gunungapi Lawu dengan ketinggian antara 2.250 - $2.911 \mathrm{~m}$ dpal, lereng terjal dengan kemiringan $>40 \%$, sebagian besar merupakan lahan gundul, dan memungkinkan terjadinya bencana lahar dingin bila terjadi hujan dengan intensitas tinggi dan durasi lama.

(b) Satuan Morfologi Lereng Gunungapi (Volcanic Slope)

Satuan ini terletak pada ketinggian 1.100 - $2.250 \mathrm{~m}$ dpal, kemiringan lereng berkisar $20-40 \%$, didominasi oleh proses erosi tebing dan gerakan massa. 
Pada satuan morfologi lereng ini mulai tumbuh vegetasi berupa hutan yang bercampur belukar.

(c) Satuan Morfologi Kaki Gunungapi (Volcanic Foot)

Ciri satuan ini adalah kemiringan lereng berkisar 8-20\%, ketinggian $550-1.100 \mathrm{~m}$ dpal, dengan vegetasi didominasi hutan hujan tropis. Proses yang sering berlangsung adalah pengangkutan, erosi, dan mulai terjadi pengendapan. Pada satuan morfologi ini banyak terdapat sesarsesar kecil searah kemiringan lereng, dan memotong relatif tegak-lurus dengan Sesar utama Lawu.

(d) Satuan Morfologi Dataran Kaki Gunungapi (Volcanic Foot Plain)

Satuan ini mempunyai lereng kemiringan $2-8 \%$, dengan proses yang dominan berupa erosi lateral dan pengendapan. Materi penyusunnya terdiri atas pasir, tuff, dan lempung yang beresistensi rendah hingga sedang, pada ketinggian antara 50 - $550 \mathrm{~m}$ dpal.

\section{Distribusi Umum Pemunculan Mataair}

Di samping faktor geomorfologi, pemunculan mataair di suatu daerah juga dipengaruhi oleh kondisi geohidrologi, yaitu: kelulusan akuifer (permeabilitas), luas daerah imbuh, dan besarnya imbuh. Jenis material batuan sangat mempengaruhi sifat kelulusan akuifer. Batuan hasil kegiatan gunungapi pada umumnya berupa lava, lahar-piroklastik, dan fragmen-fragmen individual hasil aktivitas vulkanik. Celahcelah batuan dapat menyimpan air, terutama pada endapan lava; sedangkan bahan-bahan piroklastik dapat menyimpan air dalam rongga-rongga antar butirnya, sehingga keterdapatan airtanah dapat dikatakan berada pada akuifer berproduksi sedang dengan penyebaran luas, khususnya pada gunung-gunungapi Kuarter Muda (Puspowardoyo, 1984 dalam Cahyani, 2000). Luas daerah imbuh (recharge area) mempengaruhi aliran mataair yang muncul. Morfologi kerucut gunungapi berfungsi sebagai recharge area bagi munculnya banyak mataair di daerah bawahnya. Pemunculan mataair ini berkaitan pula dengan perubahan lereng dan perubahan bahan pembentuknya, sedangkan rembesan (seepage) umumnya terdapat pada daerah-daerah yang terbatuan Tertier dengan tingkat erosi yang tinggi.

Pada sebagian lereng Barat Gunungapi Lawu, mataair dapat muncul di manamana dengan berbagai cara, tetapi distribusinya tidak merata. Distribusi pemunculan mataair berhubungan dengan keterdapatan curah hujan, karakteristik hidrologi permukaan, topografi, karakteristik akuifer, dan struktur geologinya (Tolman, 1937). Pemunculan mataair di daerah penelitian terjadi secara menyebar, terutama pada daerah yang mempunyai perubahan lereng yang tajam, karena pada bagian ini permukaan topografi memotong muka airtanah (tekuk lereng), sehingga muncul sebagai mataair topografik (topographic spring), seperti disajikan dalam Gambar 1. Selain itu mataair juga muncul pada kontak antara batuan bertekstur kasar dan batuan bertekstur halus sepanjang jalur mataair (spring belt) yang sudah tidak jelas keberadaannya. Hal ini disebabkan oleh proses erosi yang cukup intensif, sehingga mataair muncul di daerah atasnya, atau karena adanya gerakan massa yang menyebabkan mataair muncul di daerah bawahnya. Mataair di daerah penelitian pemunculannya banyak terdapat pada ketinggian $<1.500$ m dpal. 
Mataair dengan debit besar dijumpai pada daerah vulkanik berumur Kuarter dengan batuan penyusun berupa aliran lahar Lawu dan batuan piroklastik Gunungapi Lawu, yang berasosiasi dengan tekuk lereng antara morfologi lereng dengan kaki gunungapi. Di samping itu, pertemuan antara bahanbahan vulkanik yang relatif muda dan bersifat porous di bagian atas, dengan lahan yang lebih tua dan bersifat lebih kedap air di bagian bawah, juga merupakan faktor pengontrol pemunculan mataair-mataair di sekitar lokasi ini. Di samping juga keberadaan struktur sesar yang mengontrol kedua satuan morfologi ini.

\section{Klasifikasi Mataair dan Faktor Penye- babnya}

Berdasarkan sifat alirannya, pemunculan mataair dapat diklasifikasikan menjadi 3 (tiga), yaitu: mataair yang mengalir terus-menerus sepanjang tahun dan tidak dipengaruhi curah hujan (perennial spring); mataair yang mengalir beberapa bulan saja sepanjang tahun dan dipengaruhi oleh curah hujan disebut mataair temporal (intermitten spring); dan mataair yang sama dengan mataair temporal tetapi perubahan debitnya tidak langsung dipengaruhi oleh curah hujan disebut mataair periodik (periodic spring) (Tolman, 1937).

Berdasarkan klasifikasi tersebut, maka seluruh mataair yang ada di daerah penelitian dapat dikelompokkan dalam tipe mataair perenial, yaitu mataair yang mengalir sepanjang tahun. Hal ini sesuai kenyataan di lapangan, dan didukung oleh konsepsi Todd (1980), bahwa pada daerah berbatuan vulkanik merupakan tempat di mana terdapat mataair kekal, karena adanya hujan orografis sebagai input air yang selalu ada dalam

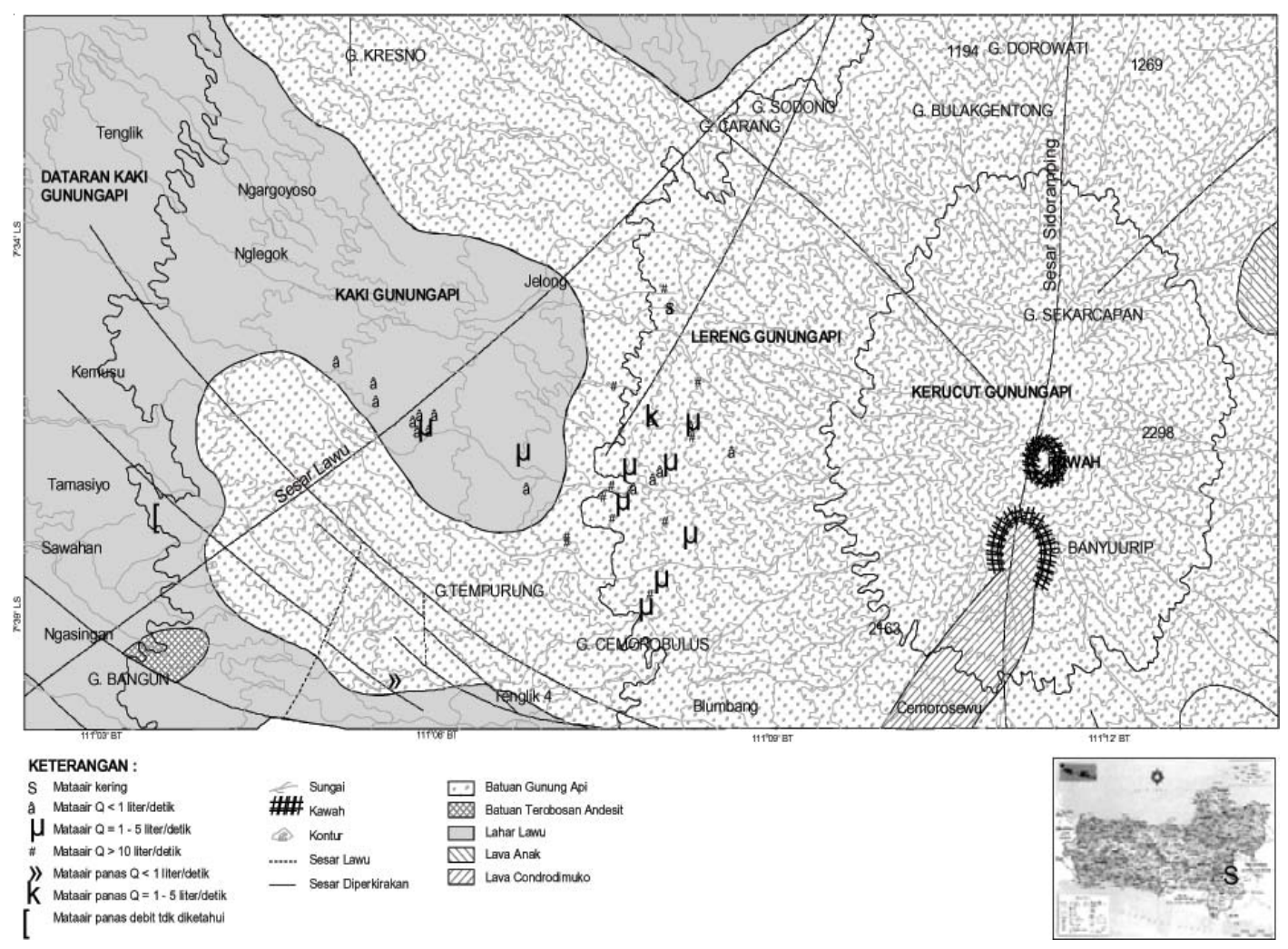

Gambar 1. Distribusi Pemunculan Mataair di Lereng Barat Gunungapi Lawu 
musim hujan maupun kemarau, yang merata hampir sepanjang tahun. Di samping itu juga dipengaruhi oleh material piroklastik yang berperan sebagai akuifer yang sangat baik.

Berdasarkan besarnya debit yang mengalir menurut Meinzer (1923) dalam Todd (1980), mataair di daerah dapat diklasifikasikan ke dalam klas III hingga VII, seperti yang terlihat pada Tabel 1. Jika ditinjau dari sebarannya, hampir semua mataair yang ditemukan terdapat pada morfologi lereng dan kaki gunungapi. Hal ini dapat dimengerti, karena kedudukan kedua morfologi ini tepat di bawah daerah hujan yang umumnya jatuh pada morfologi kerucut gunungapi. Dua faktor penyebab lokasi pemunculan mataair ini adalah: (i) adanya perubahan antar morfologi ditandai oleh adanya tekuk lereng (break of slope), dan (ii) material utama penyusun morfologi lereng dan kaki gunungapi adalah bahanbahan piroklastik di bagian atas yang berfungsi sebagai akuifer, yang didasari oleh batuan vulkanik tua (Kuarter Tua) yang relatif lebih kedap air. Air hujan yang jatuh berinfiltrasi ke dalam batuan penyusun morfologi kerucut gunungapi, mengalir ke bawah menyusuri lapisan bahan-bahan lepas piroklastik, dan muncul di sekitar tekuktekuk lereng dan kaki gunungapi, akibat pemotongan topografi permukaan dan kontak antar lapisan batuan porous di bagian atas dengan batuan kedap di bagian bawah.

Menurut Karmono dan Cahyono (1978), temperatur air tidak dibandingkan berdasarkan litologi karena tidak terdapat

Tabel 1. Klasifikasi Mataair di Daerah Penelitian Berdasarkan Debitnya

\begin{tabular}{|c|c|l|l|}
\hline Klas & Debit (Lt/det) & \multicolumn{1}{|c|}{ Mataair } & \multicolumn{1}{|c|}{ Persebaran } \\
\hline III & $28,3-283$ & $\begin{array}{l}\text { Punden Berjo, Jublek, Plesungan, Semprong, } \\
\text { Puton, dan Suren III }\end{array}$ & $\begin{array}{l}\text { Lereng dan Kaki } \\
\text { Gunungapi }\end{array}$ \\
\hline IV & $6,31-28,3$ & $\begin{array}{l}\text { Sumber Gondang, Telogo I, Semiri, Dukuh, } \\
\text { Ngerak I, dan Ngerak II }\end{array}$ & Lereng Gunungapi \\
\hline V & $0,63-6,31$ & $\begin{array}{l}\text { Ndadah, Tibogiri, Tambak, Telogo II, Telogo } \\
\text { III, Ngranten, Suren II, Ngerak III, Kalianget, } \\
\text { Kajaran I, dan Kajaran II }\end{array}$ & Lereng Gunungapi \\
\hline VI & $0,063-0,63$ & $\begin{array}{l}\text { Sumber Gombong, Sumber Jendel, Mbah } \\
\text { Sumber, Munggur, Seguwo, Nglenjing, } \\
\text { Sendang Mulyo, Puntuk, Jembangan, Talok, } \\
\text { dan Setup I }\end{array}$ & Lereng dan Kaki \\
\hline VII & $0,0079-0,063$ & Sembung & Lereng Gunungapi \\
\hline
\end{tabular}

Sumber: Analisis Data (Cahyani, 2000)

variasi nilai temperatur yang menunjukkan perbedaan jenis batuan. Temperatur mataair dipengaruhi oleh kedudukan asal air, di mana semakin dalam asal air semakin tinggi pula temperaturnya. Berdasarkan tempe- raturnya, mataair dapat diklasifikasikan menjadi 3 jenis (Tolman, 1937), yaitu:

(a) mataair dingin (cold spring), yaitu matair yang berasal dari pencairan salju atau gletser; 
(b) mataair biasa (nonthermal atau ordinary temperature springs), yaitu mataair dengan temperatur lebih dingin dari pada temperatur udara disekitarnya; dan

(c) mataair panas (thermal springs), yaitu mataair dengan temperatur lebih panas dari pada temperatur udara di sekitarnya.

Berdasarkan temperaturnya, mataair di daerah penelitian dapat diklasifikasikan seperti pada Tabel 2. Sebagian besar mataair yang ditemukan merupakan mataair biasa (non thermal springs), dengan suhu rerata $<25^{\circ} \mathrm{C}$ dan DHL rerata $<500 \mu \mathrm{mhos} / \mathrm{cm}$. Di samping itu ditemukan beberapa mataair panas, seperti di Pablengan sebanyak 9 mataair panas (thermal spring), dengan suhu berkisar 29,4 - 35,9C dan DHL antara 1.618,29 - 9.371,00 $\mu \mathrm{mhos} / \mathrm{cm}$. Mataairmataair panas ini ternyata muncul pada batas antara litologi endapan vulkanik muda dengan batuan vulkanik Kuarter Tua, dan berada di sekitar Sesar Lawu. Keberadaan perlapisan antara batuan yang lebih kompak (tua) dengan yang muda, serta terdapatnya sesar, memungkinkan proses pemanasan mataair oleh penerobosan magma melalui bidang-bidang patahan atau celah-celah yang ada. Pengaruh penerobosan magma tersebut, kemungkinan juga menyebabkan larutnya mineral-mineral tertentu dalam air, seperti: sulfur dan metana, sehingga menyebabkan pula tingginya nilai daya hantar listrik air. Contoh mataair panas ditemukan di Pablengan, Cumpleng, dan Kalianget, yang berada pada Sesar Lawu.

\section{Hubungan antara Morfologi dan Keber- adaan Sesar Lawu dengan Pemunculan Mataair di Lereng Barat Gunungapi Lawu}

Daerah penelitian berada di lereng Barat Gunungapi Lawu, yang dibatasi oleh gugusan Gunung Kresna dan Gunung
Wangi yang membentuk pegunungan Loro. Pada bagian Baratdaya Gunungapi Lawu terdapat lava flow yang mengalir membentuk deretan Gunung Cemorobulus, Tempurung, Ngargolamus, dan Gunung Bangun. Keadaan ini menyebabkan mataair muncul di sekitar lembah (intermountain valley) antara deretan pegunungan Loro dan deretan gunung-gunung di Baratdaya Gunungapi Lawu, yang memungkinkan besarnya potensi airtanah, baik yang muncul sebagai mataair atau rembesan maupun sebagai airtanah dangkal.

Menurut Purbohadiwidjoyo (1967), simpanan airtanah pada daerah yang tersusun atas batuan gunungapi Kuarter Muda akan mempunyai potensi yang baik. Daerah penelitian tersusun oleh batuan lava andesit sampai basalt berumur Kuarter Tua yang mempunyai banyak pori-pori atau lubang-lubang akibat pengkerutan bekas gelembung gas, dan bahan-bahan piroklastik berumur Kuarter Muda yang bersifat mudah meluluskan air (permeabilitas tinggi), sehingga airtanah yang terkandung di dalamnya juga besar. Di samping karena didukung oleh kondisi batuan penyusunnya, pemunculan mataair di daerah penelitian sangat dipengaruhi oleh struktur geologi regional yang ada berupa sesar. Kontrol sesar merupakan faktor yang sangat menentukan, seperti ditunjukkan pada peta pemunculan mataair di lereng Barat Gunungapi Lawu, bahwa mataair muncul bergerombol di sekitar sesar utama Lawu dan sesar-sesar yang diperkirakan (lihat Gambar 1 di muka).

Berdasarkan morfologinya, mataair terbanyak muncul pada morfologi lereng Gunungapi Lawu dengan ketinggian antara 1100 - 2000 meter dpal. Dari 47 mataair yang ditemukan, 22 mataair berada pada 
Tabel 2. Klasifikasi Pemunculan Mataair Berdasarkan Temperatur Air

\begin{tabular}{|c|c|c|c|c|}
\hline No & Nama Mataair & $\begin{array}{c}\text { Temperatur Air } \\
{ }^{\circ} \mathrm{C}\end{array}$ & $\begin{array}{c}\text { DHL } \\
(\mu \mathrm{mhos} / \mathrm{cm})\end{array}$ & Klasifikasi \\
\hline 1 & Punden Berjo & 17,7 & 175,85 & Biasa \\
\hline 2 & Sumber Gondang & 19,5 & 262,89 & Biasa \\
\hline 3 & Ndadah & 19,7 & 208,88 & Biasa \\
\hline 4 & Jublek & 19,5 & 424,05 & Biasa \\
\hline 5 & Tibogiri & 19,4 & 130,02 & Biasa \\
\hline 6 & Sembung & 18,4 & 130,02 & Biasa \\
\hline 7 & Sumber Gombong & 19,4 & 200,48 & Biasa \\
\hline 8 & Sumber Jendel & 18,4 & 199,76 & Biasa \\
\hline 9 & Tambak & 17,0 & 209,35 & Biasa \\
\hline 10 & Telogo I & 18,1 & 132,56 & Biasa \\
\hline 11 & Telogo II & 18,1 & 132,56 & Biasa \\
\hline 12 & Telogo III & 20,0 & 132,56 & Biasa \\
\hline 13 & Plesungan & 18,9 & 219,79 & Biasa \\
\hline 14 & Semprong & 18,0 & 153,57 & Biasa \\
\hline 15 & Semiri & 19,6 & 138,22 & Biasa \\
\hline 16 & Cumpleng & 35,2 & $1.623,91$ & Thermis \\
\hline 17 & Pablengan (air bleng) & 32,5 & $1.915,90$ & Thermis \\
\hline 18 & Pablengan (air obat) & 35,9 & $7.659,00$ & Thermis \\
\hline 19 & Pablengan (air kesekten) & 34,2 & $6.962,00$ & Thermis \\
\hline 20 & Pablengan (air hidup) & 29,9 & $7.242,58$ & Thermis \\
\hline 21 & Pablengan (air mati tenang) & 29,4 & $8.262,65$ & Thermis \\
\hline 22 & Pablengan (air Soda) & 30,9 & $1.658,50$ & Thermis \\
\hline 23 & Pablengan (air urus-urus) & 30,9 & $9.371,00$ & Thermis \\
\hline 24 & Ngranten & 22,9 & 180,34 & Biasa \\
\hline 25 & Puton & 19,5 & 451,49 & Biasa \\
\hline 26 & Suren II & 17,5 & 77,20 & Biasa \\
\hline 27 & Suren III & 15,2 & 86,96 & Biasa \\
\hline 28 & Dukuh & 14,7 & 104,09 & Biasa \\
\hline 39 & Ngerak I & 16,1 & 333,71 & Biasa \\
\hline 30 & Ngerak II & 20,8 & 445,89 & Biasa \\
\hline 31 & Ngerak III & 20,8 & 232,43 & Biasa \\
\hline 32 & Mbah Sumber & 20,3 & 281,67 & Biasa \\
\hline 33 & Kalianget & 33,1 & $1.618,27$ & Thermis \\
\hline 34 & Munggur & 24,8 & 156,87 & Biasa \\
\hline 35 & Seguwo & 22,4 & 257,29 & Biasa \\
\hline 36 & Tegalrejo & 23,6 & 154,84 & Biasa \\
\hline 37 & Nglenjing & 17,7 & 187,04 & Biasa \\
\hline 38 & Sendang Mulyo & 23,2 & 181,72 & Biasa \\
\hline 39 & Puntuk & 23,6 & 180,96 & Biasa \\
\hline 40 & Segendol & 17,9 & 189,30 & Biasa \\
\hline 41 & Jembangan & 18,0 & 194,32 & Biasa \\
\hline 42 & Talok & 18,5 & 298,09 & Biasa \\
\hline 43 & Setup I & 16,8 & 231,72 & Biasa \\
\hline 44 & Setup II & 16,3 & 229,30 & Biasa \\
\hline 45 & Kajaran I & 20,8 & 129,11 & Biasa \\
\hline 46 & Kajaran II & 20,8 & 135,66 & Biasa \\
\hline
\end{tabular}


morfologi lereng Gunungapi Lawu, 17 mataair berada pada morfologi kaki Gunungapi Lawu dengan ketinggian 550 1100 meter dpal, dan 7 mataair lainnya berada pada morfologi dataran kaki Gunungapi Lawu dengan ketinggian 50 - 550 m dpal.

Keberadaan mataair terbanyak ditemukan di sekitar tekuk lereng antara morfologi lereng gunungapi dengan morfologi kaki Gunungapi Lawu. Jalur-jalur mataair yang biasa disebut sabuk mataair (springs belt) sudah tidak jelas keberadaannya, artinya pola persebaran mataair sudah tidak membentuk springs belt secara sempurna. Dari peta pemunculan mataair dapat dilihat bahwa distribusi mataair tidak mengikuti pola springs belt seperti umumnya pola pemunculan mataair pada gunungapi strato. Hal ini dikarenakan Gunungapi Lawu adalah gunungapi strato tua dengan dinamika proses pengikisan dan erosi sangat kuat, sehingga penggal-penggal lereng yang menunjukkan pergantian morfologi lereng sudah tidak nampak dengan jelas. Proses gerakan massa yang selama ini terjadi juga menyebabkan tertutupnya tempat-tempat yang memungkinkan pemunculan mataair. Adanya sesar Lawu dan sesar-sesar lain yang diperkirakan juga memungkinkan munculnya mataair pada zona patahan tersebut. Sebagian besar mataair merupakan mataair rekahan yang ada kaitannya dengan pengaruh aktivitas magma, sehingga terbentuklah mataair panas. Contoh pemunculan mataair rekahan terdapat di Sumber Gondang, Desa Berjo, dan Sumber Jubelek, Desa Berjo, Kecamatan Ngargoyoso.

Pada ketinggian $1400 \mathrm{~m}$ dpal, ditemukan 5 lokasi mataair, yaitu mataair Punden Berjo, Ndadah, Sumber Gondang, Puton, dan Munggur, yang membentuk jalur mataair; kemudian hilang dan muncul lagi beberapa mataair di bawahnya, pada ketinggian 400 - $1300 \mathrm{~m}$ dpal. Berdasarkan pola yang umum dan pola garis pergeserannya, kemungkinan jalur-jalur sabuk mataair berada pada ketinggian 1400 meter dpal dan 1100 meter dpal. Namun demikian, akibat erosi lereng yang intensif dan adanya sesar Lawu, mataair muncul tidak beraturan pada lereng bagian bawahnya dengan ketinggian rata-rata 900 - 1000 meter dpal.

Kondisi mataair dengan aliran air yang deras, bersifat turbulen, dan berada pada topografi yang terjal, antara lain: mataair Suren III (917 lt/dt), yang terletak pada ketinggian $1100 \mathrm{~m}$ dpal, pada pergantian antara morfologi lereng dengan kaki gunungapi. Mataair lain yang mempunyai debit $>10 \mathrm{lt} / \mathrm{dt}$ yang berada pada pergantian lereng dan kaki gunungapi adalah mataair Punden Berjo, Sumber Gondang, Jublek, Telogo I, Plesungan, Semprong, Semiri, Puton, Dukuh, dan Ngerak II. Sebagian besar mataair muncul karena adanya sesar Lawu dan sesar-sesar yang diperkirakan.

Secara umum pola pemunculan mataair di daerah penelitian disebabkan karena muka airtanah memotong topografi sehingga muncul mataair depresi, dan juga berasosiasi dengan keberadaan sesar Lawu serta sesar-sesar yang diperkirakan. Mataair Punden Berjo dan Sumber Gondang adalah contoh mataair yang muncul karena adanya sesar, dan merupakan rekahan yang tidak terlalu dalam, sehingga muncul secara gravitatif. Mataair Cumpleng, Pablengan, dan Kalianget merupakan contoh mataair vulkanik, karena muncul melalui retakan dan terpengaruh aktivitas magma yang menyebabkan suhunya $>30^{\circ} \mathrm{C}$.

Mataair panas merupakan mataair yang disebabkan oleh tenaga non gravitasi, 
berada pada patahan kerak bumi yang panjang dan sangat dalam. Mataair panas biasanya mempunyai temperatur yang lebih tinggi dibanding air normal, dan mempunyai kandungan mineral tinggi (yang ditunjukkan oleh nilai DHL yang tinggi pula). Sumber mataair panas sebagian besar berasal dari air hujan yang jatuh di sekitar lokasi, dan hanya sebagian kecil berasal dari dalam bumi (magmatic). Air hujan jatuh mengalami infiltrasi dan masuk dalam airtanah, kemudian meresap melalui retakan atau bidang patahan dan menembus hingga batuan dasar yang sangat dalam. Air tersebut selanjutnya terpanasi oleh magma di bawahnya, dan membentuk arus konveksi besar yang mendorong ke permukaan tanah.

Proses pemunculan mataair panas di daerah penelitian berkaitan dengan aktivitas vulkanik Gunungapi Lawu. Gunungapi Lawu merupakan sumber panas bumi yang potensial, layaknya jalur gunungapi yang mempunyai sumber panas bumi di sepanjang sesar gunung berapi. Mataair panas Pablengan dan Cumpleng berada pada daerah sempit yang relatif datar dengan dikelilingi tebing terjal di deretan pegunungan Bangun. Berkembangnya struktur geologi pada lapisan batuan penyusunnya menyebabkan batuan tersebut mengalami pergeseran, terpatahkan dan terlipat. Pada daerah patahan yang merupakan zona lemah, biasanya terdapat mataair yang keluar ke permukaan. Hal ini merupakan proses yang wajar karena pada zona yang lemah tersebut akan terjadi rekahan atau celah-celah yang cukup banyak, sehingga sangat memungkinkan munculnya aliran airtanah ke permukaan. Apabila airtanah melewati jalur patahan tersebut, maka sirkulasinya akan mencapai keseimbangan, sehingga airtanah akan bergerak melalui celah-celah pada jalur patahan dan keluar sebagai mataair.

\section{KESIMPULAN}

Kesimpulan yang dapat ditarik dari pemaparan ini adalah seperti berikut.

(1) Gunungapi Lawu mempunyai potensi mataair yang besar meskipun merupakan gunungapi tipe strato tua.

(2) Persebaran mataair di lereng Barat Gunungapi Lawu sudah tidak membentuk jalur-jalur mataair yang membentuk pola seperti sabuk mataair (spring belt) secara sempurna sebagaimana pola pesebaran mataair pada gunungapi strato pada umumnya, karena disebabkan oleh proses erosi (pengikisan) dan gerakan massa yang intensif, serta keberadaan sesar Lawu dan sesar-sesar kecil di sekitarnya yang dominan mengontrol lokasi pemunculan mataair.

(3) Pemunculan mataair pada umumnya terdapat pada morfologi lereng (volcanic slope) dan kaki gunungapi (volcanic foot), dengan debit terbesar terdapat pada morfologi lereng gunungapi, yaitu mataair Suren III (917 Lt/detik) pada ketinggian 1.140 meter dpal yang berupa mataair sesar.

(4) Mataair yang muncul pada lereng Barat Gunungapi Lawu sebagian besar berasosiasi atau dikontrol oleh keberadaan sesar Gunungapi Lawu dan sesar-sesar lain yang diperkirakan dan berukuran kecil-kecil, relatif tegak-lurus dengan Sesar utama Lawu.

\section{UCAPAN TERIMAKASIH}

Ucapan terima kasih yang setinggitingginya saya sampaikan kepada Bapak Drs. Soenarso Simoen, guru saya di Fakultas Geografi UGM dulu, yang telah banyak menularkan ilmu Geohidrologi kepada saya selama ini; juga kepada Bapak Prof. Dr. 
Sutikno selaku Dosen Pembina yang telah banyak memberikan saran dan pengarahan yang baik demi kemajuan akademik dan karir saya selama ini. Ucapan terima kasih dan penghargaan yang tinggi juga saya sampaikan kepada Saudari Nur Cahyani, alumni Fakultas Geografi UGM yang telah banyak memberikan masukan data yang terkait dengan kajian ini. Semoga Allah SWT selalu melimpahkan rahmat dan hidayah-Nya kepada kita semua, amien.

\section{DAFTAR PUSTAKA}

Abdulrahman, 1990, Studi Hidrologi Mataair di Kabupaten Kuningan Jawa Barat, Skripsi, Fakultas Geografi, Universitas Gadjah Mada, Yogyakarta

Ardina-Purbo, 1985, Hubungan antara Litologi dan Luah di Pulau Jawa, Skripsi, Fakultas Geografi, Universitas Gadjah Mada, Yogyakarta

Karmono dan Joko Cahyono, 1978, Pengantar Penentuan Kualitas Air, Serayu Valley Project NUFFIC, Fakultas Geografi, Universitas Gadjah Mada,

Murdiono, 1972, Penelitian Hidrogeologi di Surakarta-Sragen, Direktorat Geologi, Bandung

Cahyani, N., 2000, Studi Mataair di Lereng Barat Gunungapi Lawu, Skripsi, Fakultas Geografi, UGM, Yogyakarta

Pannekoek, A.J., 1949, Outline of the Geomorphology of Java, E.J. Bill, Leiden

Purbohadiwidjojo, 1967, Hydrology of Strato Volcanoes, Geological Survey of Indonesia, Bandung

Sutanto, B.R, Darmakusuma, D., dan Suyono, 1980, Distribusi Kuantitatif dan Kualitatif Mataair-mataair di Lereng Merapi Bagian Selatan, Laporan Penelitian, Fakultas Geografi, Universitas Gadjah Mada, Yogyakarta

Todd, D.K., 1980, Groundwater Hydrology, John Willey \& Sons. Inc, New York

Tolman, C.F., 1937, Groundwater, McGraw-Hill Book Company, New York

Wara-Hesti-Utami, 1993, Studi Mataaair di Lereng Utara Perbukitan Rembang, Skripsi, Fakultas Geografi, Universitas Gadjah Mada, Yogyakarta 
Lampiran 1: Data Mataair di Lereng Barat Gunungapi Lawu

\begin{tabular}{|c|c|c|c|c|c|c|c|c|}
\hline \multirow[b]{2}{*}{ No } & \multirow[b]{2}{*}{ Nama Mataair } & \multicolumn{2}{|r|}{ Lokasi } & \multicolumn{3}{|c|}{ Karakteristik } & \multicolumn{2}{|c|}{ Morfologi } \\
\hline & & Koordinat & Administrasi & Tipe & $\begin{array}{c}\text { Suhu } \\
\left({ }^{\circ} \mathrm{C}\right)\end{array}$ & $\begin{array}{c}\text { Debit } \\
\text { (Lt/det) }\end{array}$ & $\begin{array}{c}\text { Elevasi } \\
\text { (m dpal) }\end{array}$ & Materi \\
\hline 1. & Punden Berjo & $\begin{array}{r}111,1279^{\circ} \mathrm{BT} \\
7,6322^{\circ} \mathrm{LS} \\
\end{array}$ & Berjo, Ngargoyoso & Rekahan & 17,7 & 154,820 & 1110 & Qlla \\
\hline 2. & Sumber Gondang & $\begin{array}{r}111,1290^{\circ} \mathrm{BT} \\
7,6307^{\circ} \mathrm{LS} \\
\end{array}$ & Berjo, Ngargoyoso & Rekahan & 19,5 & 13,786 & 1060 & Qlla \\
\hline 3. & Ndadah & $\begin{array}{r}111,1300^{\circ} \mathrm{BT} \\
7,6334^{\circ} \mathrm{LS} \\
\end{array}$ & Berjo, Ngargoyoso & Kontak & 19,7 & 2,86 & 1160 & Qlla \\
\hline 4. & Jublek & $\begin{array}{r}111,1370^{\circ} \mathrm{BT} \\
7,6353^{\circ} \mathrm{LS} \\
\end{array}$ & Tambak, Ngargoyoso & Rekahan & 19,5 & 57,612 & 1290 & Qlla \\
\hline 5. & Tibogori & $\begin{array}{r}111,1371^{\circ} \mathrm{BT} \\
7,6280^{\circ} \mathrm{LS}\end{array}$ & Gandu, Ngargoyoso & Artesis & 19,4 & 1,25 & 1420 & Qlla \\
\hline 6. & Sembung & $\begin{array}{r}111,1364^{\circ} \mathrm{BT} \\
7,6286^{\circ} \mathrm{LS} \\
\end{array}$ & Gandu, Ngargoyoso & Depresi & 18,4 & 0,029 & 1360 & Qlla \\
\hline 7. & Sumber Gombong & $\begin{array}{r}111,1352^{\circ} \mathrm{BT} \\
7,6297^{\circ} \mathrm{LS} \\
\end{array}$ & Gandu, Ngargoyoso & Depresi & 19,4 & 0,13 & 1280 & Qlla \\
\hline 8. & Sumber Jendel & $\begin{array}{r}111,1470^{\circ} \mathrm{BT} \\
7,6260^{\circ} \mathrm{LS} \\
\end{array}$ & Gandu, Ngargoyoso & Kontak & 18,4 & 0,15 & 1600 & Qvl \\
\hline 9. & Tambak & $\begin{array}{r}111,1401^{\circ} \mathrm{BT} \\
7,6377^{\circ} \mathrm{LS} \\
\end{array}$ & Tambak, Ngargoyoso & Rekahan & 17,0 & 4,783 & 1360 & Qvl \\
\hline 10. & Telogo I & $\begin{array}{r}111,1348^{\circ} \mathrm{BT} \\
7,6450^{\circ} \mathrm{LS} \\
\end{array}$ & Telogo, Ngargoyoso & Rekahan & 18,1 & 15,271 & 1240 & Qvl \\
\hline 11. & Telogo II & $\begin{array}{r}111,1358^{\circ} \mathrm{BT} \\
7,6436^{\circ} \mathrm{LS} \\
\end{array}$ & Telogo, Ngargoyoso & Rekahan & 18,1 & 2,827 & 1270 & Qlla \\
\hline 12. & Telogo III & $\begin{array}{r}111,1334^{\circ} \mathrm{BT} \\
7,6473^{\circ} \mathrm{LS} \\
\end{array}$ & Telogo, Ngargoyoso & Rekahan & 20,0 & 1,870 & 1150 & Qlla \\
\hline 13. & Plesungan & $\begin{array}{r}111,1292^{\circ} \mathrm{BT} \\
7,6350^{\circ} \mathrm{LS} \\
\end{array}$ & \begin{tabular}{|l} 
Plesungan, \\
Ngargoyoso \\
\end{tabular} & Artesis & 18,9 & 218,080 & 1150 & Qlla \\
\hline 14. & Semprong & $\begin{array}{r}111,1225^{\circ} \mathrm{BT} \\
7,6374^{\circ} \mathrm{LS} \\
\end{array}$ & \begin{tabular}{|l|} 
Semprong, \\
Ngargoyoso
\end{tabular} & Artesis & 18,0 & 115 & 1030 & Qlla \\
\hline 15. & Semiri & $\begin{array}{r}111,1225^{\circ} \mathrm{BT} \\
7,6382^{\circ} \mathrm{LS} \\
\end{array}$ & \begin{tabular}{|l} 
Plesungan, \\
Ngargoyoso \\
\end{tabular} & Artesis & 19,6 & 10,080 & 1000 & Qlla \\
\hline 16. & Cumpleng & $\begin{array}{r}111,0963^{\circ} \mathrm{BT} \\
7,6569^{\circ} \mathrm{LS} \\
\end{array}$ & \begin{tabular}{|l|} 
Cumpleng, \\
Karangpandan \\
\end{tabular} & Vulkanis & 35,2 & 0,400 & 700 & Qlla \\
\hline 17. & Pablengan & $\begin{array}{r}111,0622^{\circ} \mathrm{BT} \\
7,6345^{\circ} \mathrm{LS} \\
\end{array}$ & Pablengan, Matesih & Vulkanis & 32,5 & - & 520 & Qlla \\
\hline 18. & Ngranten & $\begin{array}{r}111,1153^{\circ} \mathrm{BT} \\
7,6268^{\circ} \mathrm{LS} \\
\end{array}$ & Ngranten,Ngargoyoso & Depresi & 22,9 & 1,83 & 900 & Qlla \\
\hline 19. & Puton & $\begin{array}{r}111,1294^{\circ} \mathrm{BT} \\
7,6175^{\circ} \mathrm{LS} \\
\end{array}$ & Puton, Ngargoyoso & Depresi & 19,5 & 49,872 & 1050 & Qlla \\
\hline 20. & Suren I & $\begin{array}{r}111,1364^{\circ} \mathrm{BT} \\
7,6065^{\circ} \mathrm{LS} \\
\end{array}$ & \begin{tabular}{|l|} 
Kemuning, \\
Ngargoyoso \\
\end{tabular} & Depresi & kering & kering & 1180 & Qvl \\
\hline 21. & Suren II & $\begin{array}{r}111,1364^{\circ} \mathrm{BT} \\
7,6065^{\circ} \mathrm{LS} \\
\end{array}$ & $\begin{array}{l}\text { Kemuning, } \\
\text { Ngargoyoso }\end{array}$ & Depresi & 17,5 & 0,378 & 1180 & Qvl \\
\hline 22. & Suren III & $\begin{array}{r}11,1364^{\circ} \mathrm{BT} \\
7,6041^{\circ} \mathrm{LS} \\
\end{array}$ & $\begin{array}{l}\text { Kemuning, } \\
\text { Ngargoyoso } \\
\end{array}$ & Rekahan & 15,2 & 917 & 1140 & Qvl \\
\hline 23. & Dukuh & $\begin{array}{r}111,1419^{\circ} \mathrm{BT} \\
7,6169^{\circ} \mathrm{LS} \\
\end{array}$ & Dukuh, Ngargoyoso & Rekahan & 14,7 & 16,340 & 1390 & Qvl \\
\hline 24. & Ngerak I & $\begin{array}{r}111,1404^{\circ} \mathrm{BT} \\
7,6227^{\circ} \mathrm{LS} \\
\end{array}$ & Ngerak,Ngargoyoso & Depresi & 16,1 & 8,263 & 1420 & Qvl \\
\hline 25. & Ngerak II & $\begin{array}{r}111,1410^{\circ} \mathrm{BT} \\
7,6242^{\circ} \mathrm{LS} \\
\end{array}$ & Ngerak, Ngargoyoso & Depresi & 20,8 & 17,227 & 1500 & Qvl \\
\hline 26. & Ngrerak III & $\begin{array}{r}111,1409^{\circ} \mathbf{B T} \\
7,6227^{\circ} \mathrm{LS} \\
\end{array}$ & Ngerak, Ngargoyoso & Rekahan & 20,8 & 0,796 & 1420 & Qvl \\
\hline 27. & Mbah Sumber & $\begin{array}{r}111,1325^{\circ} \mathrm{BT} \\
7,6310^{\circ} \mathrm{LS} \\
\end{array}$ & Selorejo, Ngargoyoso & Depresi & 20,3 & 0,520 & 1120 & Qlla \\
\hline
\end{tabular}


Lanjutan Lampiran

\begin{tabular}{|c|c|c|c|c|c|c|c|c|}
\hline \multirow[b]{2}{*}{ No } & \multirow[b]{2}{*}{ Nama Mataair } & \multicolumn{2}{|r|}{ Lokasi } & \multicolumn{3}{|c|}{ Karakteristik } & \multicolumn{2}{|c|}{ Morfologi } \\
\hline & & Koordinat & Administrasi & Tipe & $\begin{array}{c}\text { Suhu } \\
\left({ }^{\circ} \mathrm{C}\right)\end{array}$ & \begin{tabular}{|c|} 
Debit \\
(Lt/det)
\end{tabular} & \begin{tabular}{|c|} 
Elevasi \\
(m dpal) \\
\end{tabular} & Materi \\
\hline 28. & Kalianget & $\begin{array}{r}111,1349^{\circ} \mathrm{BT} \\
7,6218^{\circ} \mathrm{LS} \\
\end{array}$ & Munggur, Ngargoyoso & Vulkanis & 33,1 & 3,645 & 1180 & Qvl \\
\hline 29. & Munggur & $\begin{array}{r}111,1350^{\circ} \mathrm{BT} \\
7,6218^{\circ} \mathrm{LS}\end{array}$ & Munggur, Ngargoyoso & Depresi & 24,8 & 0,4571 & 1180 & Qvl \\
\hline 30. & Seguwo & $\begin{array}{r}111,1166^{\circ} \mathrm{BT} \\
7,6309^{\circ} \mathrm{LS} \\
\end{array}$ & Seguwo, Ngargoyoso & Depresi & 22,4 & 0,280 & 895 & Qlla \\
\hline 31. & Tegalrejo & $\begin{array}{r}111,1002^{\circ} \mathrm{BT} \\
7,6233^{\circ} \mathrm{LS}\end{array}$ & Tegalrejo, Ngargoyoso & Depresi & 23,6 & 0,210 & 750 & Qlla \\
\hline 32. & Ngenjing & $\begin{array}{r}111,09411^{\circ} \mathrm{BT} \\
7,6193^{\circ} \mathrm{LS} \\
\end{array}$ & Nglenjing, Ngargoyoso & Kontak & 17,7 & 0,750 & 710 & Qlla \\
\hline 33. & Sendang Mulyo & $\begin{array}{r}111,1020^{\circ} \mathrm{BT} \\
7,6233^{\circ} \mathrm{LS} \\
\end{array}$ & $\begin{array}{l}\text { Sendang Mulyo, } \\
\text { Krg.pandan }\end{array}$ & Kontak & 23,2 & 0,287 & 770 & Qlla \\
\hline 34. & Puntuk & $\begin{array}{r}111,1028^{\circ} \mathrm{BT} \\
7,6211^{\circ} \mathrm{LS} \\
\end{array}$ & Puntuk, Karangpandan & Kontak & 23,6 & 0,289 & 780 & Qlla \\
\hline 35. & Segendol & $\begin{array}{r}111,0996^{\circ} \mathrm{BT} \\
7,6248^{\circ} \mathrm{LS} \\
\end{array}$ & Segendol, Karangpandan & Depresi & 17,9 & - & 750 & Qlla \\
\hline 36. & Jembangan & $\begin{array}{r}111,0883^{\circ} \mathrm{BT} \\
7,6141^{\circ} \mathrm{LS} \\
\end{array}$ & \begin{tabular}{|l|} 
Jembangan, \\
Karangpandan \\
\end{tabular} & Depresi & 18,0 & 0,222 & 680 & Qlla \\
\hline 37. & Talok & $\begin{array}{r}111,0937^{\circ} \mathrm{BT} \\
7,6168^{\circ} \mathrm{LS} \\
\end{array}$ & Talok, Karangpandan & Depresi & 18,5 & 0,843 & 730 & Qlla \\
\hline 38. & Setup I & $\begin{array}{r}111,1005^{\circ} \mathrm{BT} \\
7,6211^{\circ} \mathrm{LS} \\
\end{array}$ & Setup, Karangpandan & Depresi & 16,8 & 0,194 & 760 & Qlla \\
\hline 39. & Setup II & $\begin{array}{r}11,10063^{\circ} \mathrm{BT} \\
7,6235^{\circ} \mathrm{LS} \\
\end{array}$ & Setup, Karangapandan & Rekahan & 16,3 & 1,541 & 760 & Qlla \\
\hline 40. & Kajaran I & $\begin{array}{r}11,10063^{\circ} \mathrm{BT} \\
7,6287^{\circ} \mathrm{LS}\end{array}$ & Ngelorok, Ngargoyoso & Rekahan & 20,8 & 3,111 & 1170 & Qlla \\
\hline 41. & Kajaran II & $\begin{array}{r}11,10063^{\circ} \mathrm{BT} \\
7,6287^{\circ} \mathrm{LS} \\
\end{array}$ & Ngelorok, Ngargoyoso & Rekahan & 20,8 & 4,251 & 1170 & Qlla \\
\hline
\end{tabular}

Sumber: Hasil Survei Lapangan (Cahyani, 2000) 